\title{
HIPPONA DZIŚ
}

Ruiny starożytnej Hippony leża około $3 \mathrm{~km}$ na południowy zachód od centrum algierskiego portu Annaba. Rozpoznana archeow logicznie część antycznego miasta połoźona jest u ujścia rzeki Seybouse do Morza Sródziemnego, nad głęboka zatoką tworząca naturalny port. Kiedy u schyłku IX w. prz. Chr. rozpoczęła sie fenicka kolonizacja wybrzeży Afryki Północnej, powstała najpierw Kartagina, a po niej inne fenickie miasta wzdłuz afrykańskiego wybrzeża. Jednym z nich była Hippona, której nazwa pochodzi, być może, od fenickiego słowa Ubbōn, co oznacza port, schronienie. Państwo kartagińskie rosło stopniowo w potegge, podporzadkowując sobie słabszych sąsiadów - plemiona Afrów 1 Numidów. Jednak stopniowo, poza Kartagina, na zapleczu jej afrykańskiego państwa, zmieniał się układ sił politycznych. Ekspansja kartagińska przyspieszyła bowiem proces formowania się królestw lokal nych zwanych najczęściej numidyjskimi, z których królestwo Massyliów graniczyło od południowego zachodu z terytorium kartagińskim. Doszło ono do najwiekszej potegl w III w. prz. Chr., a jego władca Masynissa, jako sojusznik Rzymu, powiększył terytorium państwa kosztem ziem osłabionej po II wojnie punickiej Kartaginy. Właśnie z począków III w. prz. Chr. pochodzá pierwsze, archeologicznie uchwytne ślady osadnictwa miejskiego na terenie IIippony. Mílasto było obok stołecznej Cyrty rezydencją królów numidyjskich 1 dlatego nazwano je Hipponaz Królewską. Po pokonaniu Jugurty, ostatniego wybitnego władcy numidyjskiego 1 zlikwidowaniu niezależności Numidii w połowie I w. prz. Chr., Hippona dostaje się pod panowanie rzymskie i staje sie stolica nowej rzymskiej prowincji Africa Nova. Po zakończeniu wojen domowych August nadaJe Hipponie status municypium, a potem Trajan podnosi ju do rangi kolonii. W okresie cesarstwa Hippona oagrywała ważia rolę w zaopatrzeniu Hzymu w zboże i oliwę, gdyż wokolicy miasta znajdowały sie liczne fundi, czyli wielkie liajitki rolne produkujące zboże na eksport. Centrum miasta stanowilo foruil, ośro- 
żonego prostokąta $i$ zbudowane zostało za panowania Wespazjana przez prokonsula C. Pacjusza Africanusa. Otaczały je z trzech stron portyki, ulubione wafryce, gdyż chroniły odwiedzających forum przed słonecznym żarem. Nie opodal leżało centrum handlowe z licznymi sklepami 1 warsztatami rzemieślniczymi. Wśród innych budowli publicznych, odsłonietych wipponie, na uwage zasługuje teatr, odsłonięty tylko czéściowo oraz dwie wielkie łaźnie z epoki Sewerów. Podstawowa mase mieszkańców Hippony stanowiła ludność pochodzenia libijskiego, wśród której głęboko zakorzeniła się punicka mowa, religia 1 kultura. Jednak u schyłku I w. arystokracja municypalna zaczęza odwracać się od kultury punickiej romanizując się szybko, a kultura punicka stała się obok kultury autochtonicznej, libijskiej, kulturą mas wiejskich słabo zromanizowanych. Kultura ta okazała się jeanak niezwykle zywotna wśród mas ludowych, a o jej trwałości świadczy wiadomość podana przez św. Augustyna, że jeszcze na początku V wiejskie gminy chrześcijańskie w rejonie Hippony nie mogły obejść się bez kapłanów rładających językiem punickim.

O początkach cinześcijaństwa w Hipponie nie mamy żadnych pewnych wiauowości. Być może gmina chrześcijańska pojawiła się w mieście w poczaztkach III wieku. Pierwszym znanym z imienia biskupen Hippony by $\mathbf{s}$ s. Teogenes, który brał udział w synodzie w Kartaginie w 256 roku. Biskup ten wraz z 36 wiernymi poniósł smierć męczeŕskia podczas prześladowania chrześcijan za panowania Waleriana w styczniu 259 roku. Cnrześcijaństwo czyniło W III w. szybkie nostępy w Afryce, szczególnie w miastach, 1 władze uznawały je za zagrozenie dla rzyinskiego porządku. W roku 250 cesarz Decjusz nakazuje wszystkim obywatelom uczestniczenie wroczystym składaniu oflar bogom w celu umocnienia jedności państwa. Odmowa powoduje represje, pojawia sie problem odstępców. Problem odstępców 1 traditores zaostrzył się szczególnie podczas prześladowań za panowania Diokleojana $i$ coraz wyraźniej zaczał dzielić afrykańskie chrześcijaństwo na dwa wrogie obozy, aby w roku 312 doprowadzić do rozłamu w jego łonie. Kazdy z dwu powstałych Kościołów głosił, iź jest jedynym, prawdziwym i powszechnym - katolickim, totez terminu katolicki użya się w odniesieniu do oficjalnego Kościoła rzymskiego, walczącego z Kościołen schizmatyckim. Walce z donatystami poświęcił wiele wysiłku najsłynniejszy biskup 
Hippony - sw. Augustyn, który został wybrany na rzadce diecezj1 w 396 roku. Gdy obejmowal we wadanie swą diecezje, donatyści stanowili wiej wiekszośc 1 biskup musiał prowadzić z nimi uporczywa walke. Polemice z donatystami poświecil on znaczna część swoj imponującej twórczośc1 literackiej, zwalczając 1ch przede wszystkim słowem jako znakomity kaznodzieja. Kulminacyjnym momentem $w$ walce $z$ donatyzmem była publiczna dysputa miedzy biskupami donatystycznymi a katolickimi podczas synodu - Kartaginie 411 roku. Miała ona rozstrzygnąć, któ ry z dwóch Kościołów jest prawdziwy, a zatem jedynie legalny. Biskupom katolickim przewodzili ś⿴. Alugustyn, biskup Hippony 1 Aureliusz, biskup Kartaginy. W wyniku dyskusji donatyzm został potepiony, a jego zwolennicy poddani represjom, które stopniowo pozbawiły ich znaczenia 1 punktów oparcia.

Wiosná 429 r. W Afryce Północnej pojawili się germańscy Wandalowie, których najazdu nie zdołała powstrzymać armia rzymska. W 430 roku Wandalowie oblegaja Hippone, gdzie podczas oblezienia 28 sierpnia umiera św. Augustyn. Miasto poddaje sie najeźdźcom dopiero po rocznym oblęzeniu w sierpniu 431 roku. Słaba armia rzymska nie jest w stanie odeprzeć napastników, których zagony niszcza 1 rabuja kwitnące miasta 1 wsie Numidil 1 Afryki Prokonsularnej. Wiele miast zostaje złupionych, zdewastowanych 1 niemal całkowicie wyludnionych. Los taki spotyka takze Hipponę, która ulega degradacji. Panowanie wandalskie we wschodniej części Afryki Pónnocnej trwało ponad stulecie 1 zakończyło sie dopiero 532 r., kiedy armia bizantyjska przywróciła na ponad sto lat panowanie wschodnich cesarzy nad tą częściá Afryki rzymskiej. Do głosu dochodza coraz częściej miejscowe autochtoniczne plemiona nomadów lub półnomadów tworzace nietrwałe królestwa 1 mdzierające się z pustyni na urodzajne tereny za niszczejacym limesem. Przybycie Arabón połowie VII n. położyło kres późnorzymskiej cywilizacji na terenie Afryki Północnej. Hippona po podboju arabskim egzystuje jako mała mieścina noszaca arabską nazwe Būna, o której wspaniałej przeszłości pamiętaja juz tylko historycy. WX w. teren antycznego miasta zostaje opuszczony, a nowe miasto arabskie powstaje wiejscu, gdzie dziś leży port Annaba.

Odkrycie wczesnochrześcijańskiej Hippony zuwdzięczamy wykopaliskom, które prowadził na terenie antycznego miasta fran- 
cuski badacz Erwan Marec. Wyniki wykopalisk w tziv. dzielnicy. chrześcijańskiej zostały opublikowane w 1958 roku ${ }^{1}$. Dominująca bulowla w tej części miasta była trzynawowa bazylika orientowana na północny zachód, której wymiary wynoszą 37,5 m długośc1 i 18,5 m szerokości. Kościół miał kształt wydłużonego prostokąta zakończonego wydłużoną absydą. Wnętrze podzielone było na trzy nawy dwoma rzędami prostokątiych słupów po 10 w rzędzie. Słupy te, stojace w odlegtosci $2,5 \mathrm{~m}$ od siebie, zbudowane były z bloków kainiennych pokrytych prawdopodobnie malowaná zaprawa. Sciany zewnętrzne kościoła wykonane były ze zwykłych kamieni 1 wzmocnione co 2 m odcinkami wykonanymi z bloków piaskowca. Na podstawie znalezionych we wnętrzu kościoła fragmentów dachówek można przypuszczać, że dach miał konstrukcje drewniana kryta dachówkami. Absyda miała $8,5 \mathrm{~m}$ szerokośc1 $17 \mathrm{~m}$ głębokości i przykryta była półkopuła wykonaną z naczyń glinianych zatkniętych jedno w drugie i spojonych zaprawą. W części prostokątnej absydy znajdowaty sie przejścia do pomieszczeń bocznych, a w części wyokragglonej murowana ława dla duchowieństwa, która miała $45 \mathrm{~cm}$ wysokości i $52 \mathrm{~cm}$ szerokości, a w środku na osi budowli, była przerwa dla tronu biskupa. Posadzke absydy wyniesiono około pół metra nad poziom nawy głównej, zaś przestrzeń dookoła ołtarza wydzielono prawdopodobnie od reszty kościoła przy pomocy niskich murków. Około 1,5 m przed tymi murkami odsłonięta była w nawie głównej kościoła kamienna podbudowa o wymiarach $3,8 \times 3 \mathrm{~m}$, na której ustawiano podium dla lektora. Wnętrze kościoła pokrywały mozaiki podłogowe, których styl pozwolił ustalić lata budowy. Bazylika powstała prawdopodobnie miedzy latami 324-362, gdy miejscowy biskup otrzymał subwencje na rozbudowe starszego kościoła. Obok kościoła, przy jego wschodniej ścianie, zbudowano baptysterium. Zespół ten składał sie z trzech pomieszczeń - sali z basenem chrzcielnym, podłużnej sali zakoŕczonej absyda i sali z mozaikiz. Basen chrzcielny miał głębokość jednego metra i wymiary 1,35 x 1,95 m. Nad basenem umieszczone było cyborium wsparte na czterech murowanych kolumnach. W dnie basenu stwierdzono kanaty do odpro-

1 E. Marec, Monuments chrétiens d'Hippone ville épiscopale de Saint Augustin, Paris 1958. 
wadzania wody. Sala z absyda, przylegajaca do sali chrzcielnej od północy, pełniła prawdopodobnie funkcje katechumeneum, a sala z mozaiką, leżąca obok, była consignatorium. W pobliżu bazyliki znajdowal sie klasztor oraz kaplica w formie trichory.

W pismach św. Augustyna można znaleźć liczne informacje o chrześcijańskich budowlach sakralnych w Hipponie ${ }^{2}$. Lista 1ch ułożona w porządku chronologicznym przedstawia się następująco:

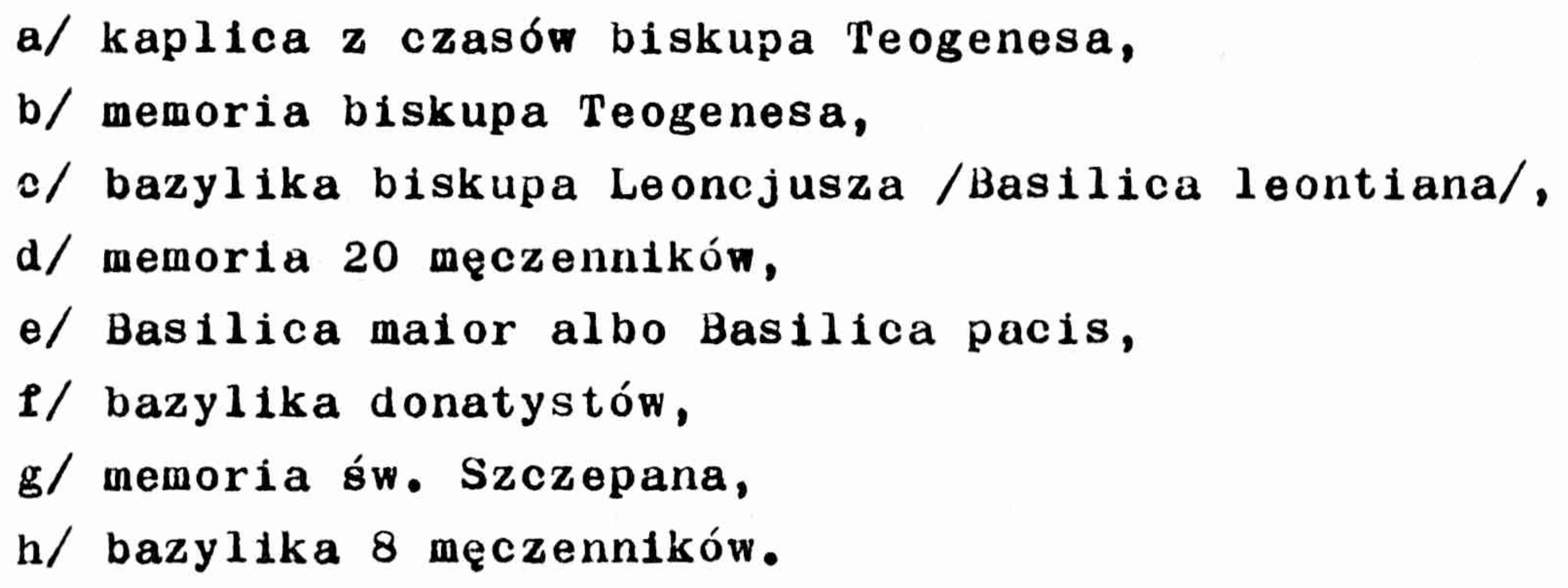

Najstarsza kaplica z czasów biskupa Teogenesa została najprawdopodobniej wchłonięta przez późniejszy kościół katedralny 1 nie pozostał po niej żaden ślad. Memoria ku czci biskupa Teogenesa zbudowana po jego męczeńskiej śmierci w $259 \mathrm{r}$. oraz memoria ku czci 20 męczenników wzniesiona po ich śmierci w 304 r., znajdowały się, jak przypuszcza E. Marec, na cmentarzach poza murami miasta, gdzie leżała także bazylika 8 meczenników wzniesiona przez kapłana Leporiusza w latach 425-426. Bazylika donatystów leżała prawdopodobnie winnej, nieodsłoniętej dotychczas czéści miasta. E. Narec uważa, iż bazylike biskupa Leoncjusza należy utożsamiać z tzw. "kościołem o pięciu nawach", który położony jest po drugiej stronie szerokiej ulicy, vis à vis trzynawowej bazyliki. Budowla ta, jego zdaniew, powstała przez powiększenie pierwotnego kościoła domowego 1 do niej należy odnosić określenie antiqua ecclesia spotykane w tekstach św. Augustyna. Jednak plan tej budowli odbiega bardzo od planu wykstałconej bazyliki wczesnochrześcijańskiej ${ }^{3}$. Wielka trzynawowa bazy-

2 o. Perler, L'Église principale et les autres sanctualres chrétiens d Hippone-la-Royale d apres les textes de saint Augustin, REAug 1/1955/299-343; E. Marec, dz.cyt., 215-234.

3 Jean Lassus w przedmowie do ksiażki E. Mareca wyraża wątpliwośc1 co do chrześcijańskiego charakteru tej budowli. 
lika dominujaca w tej części miasta to, jak uważa E. Marec, kościóz, który występuje w tekstach św. Augustyna jako basilica pacis lub basilica maior, i należy go identypikować jako kościół katedralny. Położona nie opodal trichora jest prawdopodobnie wzniesiona przez dịakona Erakliusza w 425 r. meinoria ku czci św. Szczepana, protomęczennika.

Dzicki badaniom archeologicznym prowadzonym na terenie starożtnej Hippony dobrze poznano dzielnice chrześcijanska z jej główrą budowly - kościołem katedralnym. Uważna lektura tekstów św. Augustyna pozwala nam tchnąć zycie w odsłonięte ruiny i umiejscowić w fch murach wiele wydarzeń z życia sławnego biskupa, który ponad 30 lat kierował kościołem wipponie.

Tadeusz Gołgowsk1 - Warszawa

DE HIPPONE REGIO

/Argumentum/

Hac in dissertatiuncula historia necnon monumenta archeologica antiqui Hipponis legil tempore S. Augustini vigentia breviter exponuntur. 